\title{
Assessment of cellular and humoral immunity of myasthenics
}

\author{
SHIH-WEN H UANG, JOHN W. ROSE, AND RICHARDF. MAYER \\ From the Departments of Pediatrics and Neurology, University of Maryland School of Medicine, \\ Baltimore, Maryland 21201, USA
}

SUMMARY A close association of autoimmune diseases or autoimmune phenomena in myasthenia gravis is well known. A comprehensive immunological study of 22 patients with myasthenia gravis showed that changes in the immune system mainly involve the thymusderived lymphocytes ( $\mathrm{T}$ cells). Anti-thymus antibody was present in $90 \%$ of the patients, and it paralleled the frequency of thymic abnormality in myasthenia gravis. It is postulated that in myasthenia gravis the altered $\mathrm{T}$ cell functions caused by anti-thymus antibody result in the formation of an array of autoantibodies including the factor which blocks the neuromuscular transmission.

Myasthenia gravis has been considered to be an autoimmune disease (Smithers, 1959; Nastuk et al., 1960; Simpson, 1960). In most myasthenic patients the histology of the thymus has been reported to be abnormal, showing hyperplasia or, less often, a thymoma. A possible linkage between the thymic abnormality and the development of autoimmunity in myasthenia gravis has been suggested in the animal model (Yunis et al., 1971) and in man (Simpson, 1960, 1966; Adner et al., 1966; Simpson et al., 1976). Recently, abnormal thymic lymphocyte functions of patients with myasthenia gravis were suggested in in vitro tests (Armstrong et al., 1973; Field et al., 1973; Mori and Kawanami, 1973; Goust et al., 1974; Simpson et al., 1976). The purpose of this paper is to report a comprehensive immunological study of myasthenia gravis and to construct a hypothesis that a circulating antibody to thymic cells may have led to the thymic dysfunction and subsequent development of autoimmune phenomena.

This study was partly supported by Grant No. CA 15611-01 from the National Cancer Institute, US Public Health Service and the Potomac Valley Chapter of the Myasthenia Gravis Foundation. J. W. Rose was the recipient of a Henry R. Viets Medical Student Research Fellowship from the Myasthenia Gravis Foundation.

Address for correspondence and reprint requests: Shih-Wen Huang, MD, Department of Pediatrics, University of Maryland Hospital, 22 South Greene Street, Baltimore, Maryland 21201, USA.

Accepted 23 May 1977

\section{Patients and methods}

The patient population of 22 consisted of 15 females and seven males, aged 8 to 77 years. All the patients had well-documented myasthenia gravis by physical examination, electrophysiological testing, and response to anticholinesterase drugs. Duration of symptoms ranged from three months to 27 years. Three patients had localised myasthenia and 19 patients had generalised myasthenia. Three patients were known to have had thymoma; one thymoma was malignant and associated with pemphigus vulgaris. Other significant concurrent illnesses in the population studied included hyperthyroidism (one case), multiple sclerosis (one case), and recurrent optic neuritis (one case). At the time of the study, three patients were on no therapy, 18 were taking either pyridostigmine or neostigmine, and one patient was on prednisone therapy. Four patients had undergone thymectomies from six months to five years before the study. A control of 22 age-matched, healthy individuals was included for the screening of autoantibody in the sera.

LYMPHOCYTE SEPARATION

Heparinised blood was collected and its lymphocytes were isolated after a separation with FicollHypaque gradient (Boyüm, 1967). Cells were washed three times with minimum essential medium (MEM). Ninety to $95 \%$ of the lymphocytes were recovered by this technique and $100 \%$ were viable. 
T CELLS

A sample of $4 \times 10^{6}$ lymphocytes in $0.2 \mathrm{ml}$ of MEM was incubated with $0.2 \mathrm{ml}$ of $15 \%$ freshly washed sheep red blood cells (SRBC) at room temperature for five minutes (Jondal et al., 1972). After the incubation, the cell suspensions were centrifuged at $200 \mathrm{~g}$ for 15 minutes. Cells were then left at $4^{\circ} \mathrm{C}$ for at least an hour and were counted within two hours. The pellets were gently disrupted before counting. At least 200 lymphocytes and rosettes with three or more SRBC per lymphocyte (RFC) were counted.

BONE MARROW DERIVED LYMPHOCYTES (B CELLS) Cells were identified by immunoglobulin determinants on the surface by means of the indirect immunofluorescence technique (Ross et al., 1973).

LYMPHOCYTE STIMULATION TESTS

A whole blood micromethod (Junge et al., 1970) was used for short-term cultures. Mitogens were phytohaemagglutinin (PHA-Difco, Michigan), concanaval in A (Con A-Sigma), and pokeweed mitogen (PWM-Difco). All tesis were performed in triplicate along with a set of control cultures without mitogens. The culiure was maintained at $37^{\circ} \mathrm{C}$ in $\mathrm{CO}_{2}$ incubator for 72 hours; $1.25 \mu \mathrm{Ci}$ of $\left({ }^{3} \mathrm{H}\right)$ thymidine $(6.50 \mu \mathrm{Ci} / \mathrm{m}$ mole $)$ was added and incubation continued for eight hours. The cells were harvested and subjected to scintillation counting. Stimulation Index (SI) was ob:ained as follows: $\mathrm{SI}=\left({ }^{3} \mathrm{H}\right)$ thymidine uptake (cpm) of stimulated culture $/\left({ }^{3} \mathrm{H}\right)$ thymidine uptake of unstimulated culture.

MEASUREMENT OF SERUM IMMUNOGLOBULINS

Serum IgG, IgM and IgA were measured by radial immunodiffusion (Meloy immunodiffusion plates). Serum IgE was measured by solid-phase radioimmunoassay using the 'Phadebas' Kit (Pharmacia) in which the anti-IgE was raised in rabbits.

DETERMINATION OF SERUM AUTOANTIBODY Antiorgan, antitissue antibody Indirect immunofluorescence techniques were used to detect the presence of antinuclear antibody (ANA), antismooth muscle antibody (ASMA), antimitochondrial antibody (AMCA) and antiparietal cell antibody (APCA) on frozen sections of rat stomach. Antiadrenal antibody (AADA) and antithyroid antibody (ATRA) were detected on frozen sections of human tissues obtained from necropsy. Antithyroglobulin antibody (ARGA) was determined by the haemagglutination method (Burroughs-Wellcome).
AntiDNA antibody Antidouble-stranded DNA (DS-DNA) and single-stranded DNA (SS-DNA) antibodies were detected by the haemagglutination technique using human group $\mathrm{O} \mathrm{Rh}(-)$ blood as a carrier and $\mathrm{CrCl}_{3}$ as a coating agent (Vyas et al., 1968; Ammann and Pelger, 1972). Both DS-DNA were prepared from calf thymus (Sigma). Haemagglutination titre was reported as a reciprocal of the endpoint.

Antithymus antibody (ATA) Four fresh normal human thymuses obtained from patients who underwent cardiac surgery were dispersed into cell suspensions. Antibody was determined by the presence of a rim pattern by an indirect immunofluorescence technique. Patient sera were diluted $1: 10$. At least 200 thymic cells were counted. If less than $5 \%$ were stained positively, the specimen was considered negative. The antithymus antibody of the serum was considered to be positive if the reaction was noted in tinree out of four thymic cell preparations.

\section{Results}

When the estimate of the subpopulation of lymphocytes, $T$ cells, and $B$ cells, was made, both the absolute number of cells per unit and the percentage of the respective cells in the total population of lymphocytes were considered. Among 22 myasthenia gravis patients studied, seven had an abnormally low percentage and absolute numbers of $\mathrm{T}$ cells while an additional three had only a low percentage of $\mathrm{T}$ cells (Fig. 1). All patients had normal B cells except for six patients who had B cells above $25 \%$ in their peripheral blood which was considered the upper limit of the normal range (Fig. 2). The serum immunoglobulin levels were normal except in two patients who had slightly elevated IgA and four who had slightly raised IgM. Three patients were found to have a significantly raised value of IgE (Fig. 3).

In the study of lymphocyte stimulation with mitogens, four patients had significantly poor response to all three mitogens while four others responded poorly only to Con A (Fig. 4). It was also found that all four poor responders to three mitogens and two of the poor responders to Con $\mathrm{A}$ had abnormal numbers and percentage of $\mathrm{T}$ cells.

The Table summarises the results of autoantibody screening. One of the most striking features was the high incidence of antithymus antibody (ATA) among patients (Fig. 5). Two patients who had no demonstrable ATA were in an inactive stage of their disease as judged by clinical criteria. 


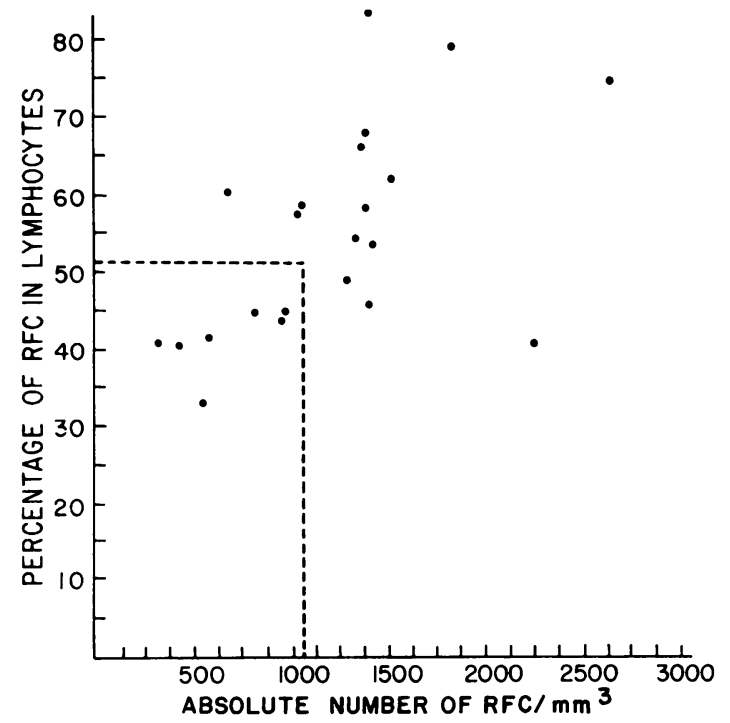

Fig. 1 Distribution of rosette forming cells ( $T$ lymphocyte) in 22 myasthenia gravis patients. Broken lines indicate lower limit of normal (mean $\pm 2 S D$ ).

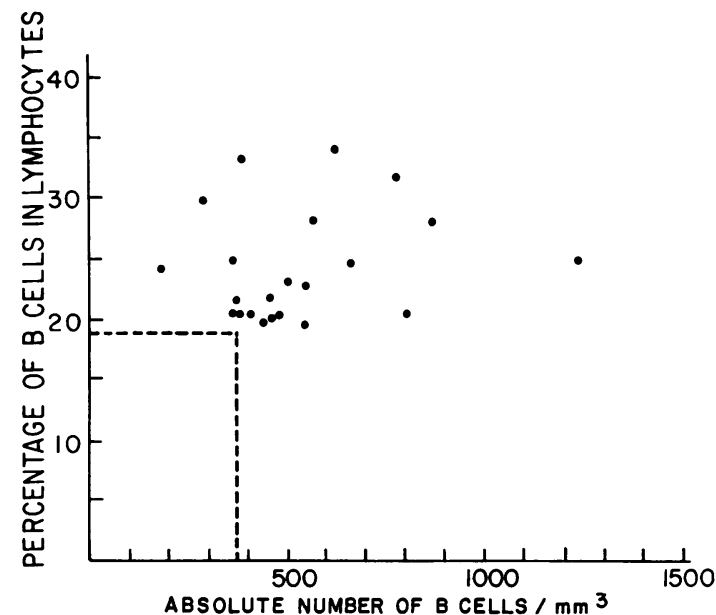

Fig. 2 Distribution of $B$ cells in 22 myasthenia gravis patients. Broken lines indicate lower limits of normal (mean $\pm 2 S D$ ).

Except for one patient, all six who had low $\mathrm{T}$ cells had a significant titre of ATA to all thymic cell preparations as judged from the increased numbers of fluorescent-positive cells. In some preparations, as many as $45 \%$ of thymic cells were found to be bound by ATA in the sera. All the sera of age-matched control subjects were nega-

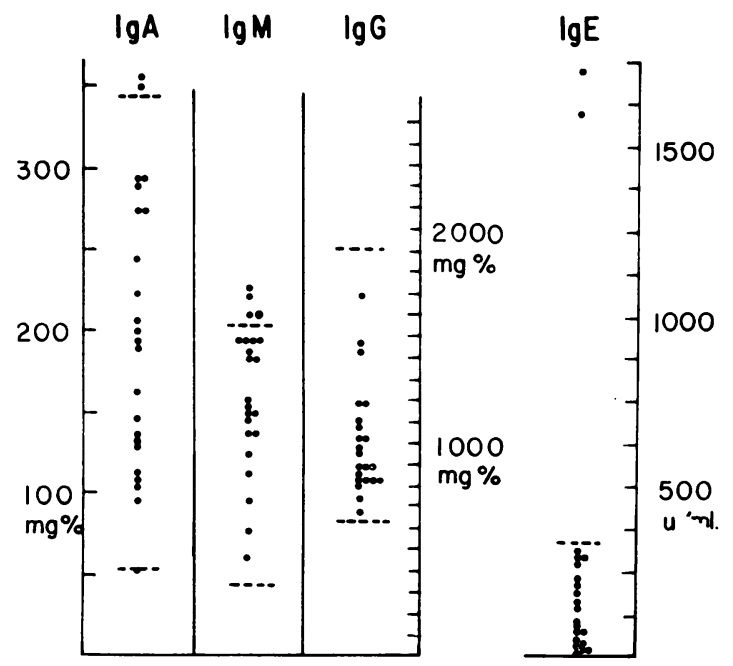

Fig. 3 Serum immunoglobulin levels of myasthenic patients. Dotted lines indicate normal range (mean $\pm 2 S D)$.

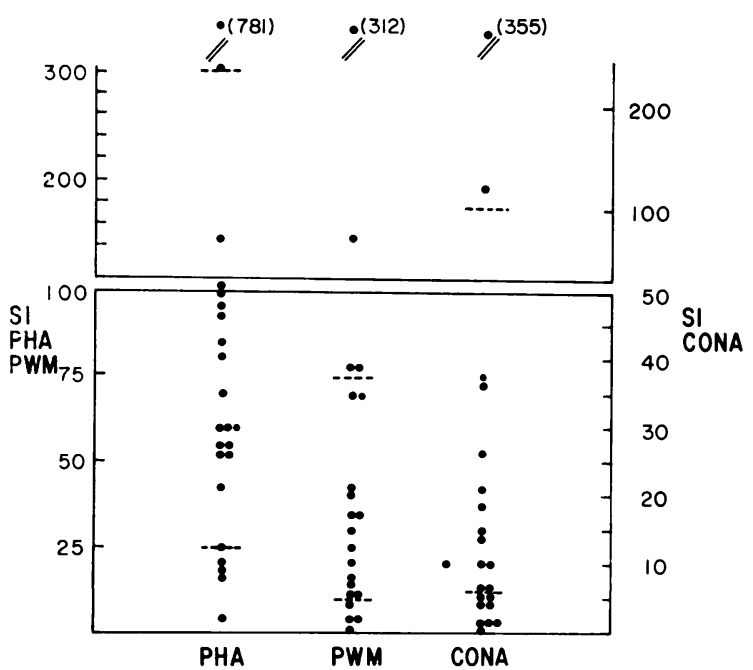

Fig. 4 In vitro response to mitogen stimulation of myasthenia gravis lymphocytes. The bar denotes mean $\pm 3 S D$ of 20 normal controls.

tive for ATA. Another significant finding was the high incidence of DNA antibody among the myasthenic patients studied. Nine of 22 had significant antibody titres to SS-DNA, and of these three also had antibody to DS-DNA. One of the latter was suspected of having systemic lupus erythematosus. In five patients we observed 
Table Results of autoantibody screening

\begin{tabular}{lrr}
\hline Laboratory tests & Positive & $\%$ \\
\hline Antinuclear Ab & $3 / 22$ & 13.5 \\
Antiparietal cell Ab & $1 / 22$ & 4.5 \\
Antithyroid Ab & $5 / 22$ & 22.5 \\
Antiadrenal Ab & $1 / 22$ & 4.5 \\
Antiskeletal muscle Ab & $4 / 22$ & 18.0 \\
Antithyroglobulin Ab & $2 / 22$ & 9.0 \\
AntiDNA Ab & & \\
DS-DNA Ab & $3 / 22$ & 13.4 \\
SS-DNA-Ab & $9 / 22$ & 40.5 \\
Antithymic cell Ab & $20 / 22$ & 90.9 \\
Antimitochondrial Ab & $0 / 22$ & 0.00 \\
\hline
\end{tabular}

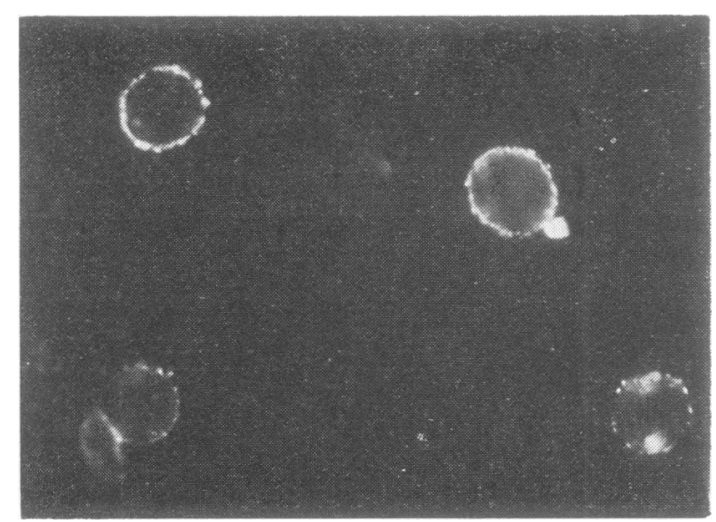

Fig. 5 Positive immunofluorescent pictures of normal thymic cells with serum from a myasthenia gravis patient as a source of antibody.

that their sera had more than three demonstrable autoantibodies. By using the same technique, no autoantibody was found in the control sera.

\section{Discussion}

The frequent occurrence of thymic abnormalities and of autoimmune diseases in myasthenia gravis prompted us to investigate the status of both the cellular and humoral immune system of patients. Among the patients studied, we observed a significant decrease of $T$ cells in one-third of cases. Since the changes of B cells appeared minimal, it would reflect an increase in the third population of lymphocytes which lack identifiable cell markers (null cells). Those findings appeared dissimilar to some reports (Koziner et al., 1976; Simpson et al., 1976) but similar to others (Lisak, et al., 1976). The cause of the dissimilarity among the reports could be largely due to the age or different stage of the disease of subjects studied. Also, some technical difference in measuring cell markers among the investigators should not be ignored. However, those observations, in our patients appeared compatible with reports on other autoimmune diseases such as systemic lupus erythematosus (Stutman, 1972; Stobo et al., 1972; Williams et al., 1973) and rheumatoid arthritis (Williams et al., 1973). In systemic lupus erythematosus (Stobo et al., 1972; Stutman, 1972; cytes has been observed even before the emergence of autoantibody in the sera (Stutman, 1972). Therefore, both early and longitudinal observations on changes of lymphocyte markers or on other immunological findings may be of some value in monitoring the progress of autoimmune processes.

A good correlation was found between the changes of $\mathrm{T}$ cells and their response to in vitro stimulation. All patients who had low RFCs, both in percentage and in number, had at least one abnormal response to mitogen stimulation. Since the cell numbers were all adjusted for the condition of optimal stimulation, a poor response usually indicated alteration of $\mathrm{T}$ cell membrane. It was found that the alteration might have occurred in preference to receptor of Con A since eight patients showed poor responses in contrast with four who showed poor response to PHA and PWM respectively. This finding confirmed a previous report (Armstrong et al., 1972) although its exact cause is still unknown. Our observations, however, did not exclude a possibility that many patients could have other subtle changes on lymphocytes as described by Simpson et al. (1976) with a different in vitro culture technique.

In searching for abnormal serum immunoglobulin levels among patients, we found three cases who showed a significantly raised IgE. There was no indication that those patients had either an allergic disorder or parasitic infestation which are known to enhance IgE responses. It was recently suggested that in some $\mathrm{T}$ cell disorders an elevated IgE may have resulted from the loss of $\mathrm{T}$ cell suppressor activity (Waldmann et al., 1974). It is possible that in some myasthenia gravis patients the alteration of $T$ cells may have enhanced the production of IgE. It is also intriguing to investigate the nature of these $\operatorname{IgE}$ antibodies since, in some autoimmune diseases, IgE has been shown to have autoantibody activity, such as antinuclear antibody (Miyawaki and Ritchie, 1974). We did not find any selective IgA deficiency in our patient group as was indicated by another study (Simpson et al., 1976). However, it confirms our notion that myasthenia gravis patients may present with a wide range of altera- 
tion in thymic functions. Those with $\operatorname{IgA}$ deficiency may have lost their helper cell function (Hobbs, 1968).

Another significant indication that, in many myasthenics, $T$ cells might have lost their suppressor activity was indicated by the presence of an array of autoantibodies in their sera. Findings of ATRA, ANA, APCA, and AADA had been reported previously (Simpson, 1966; Osserman, 1969; Penn et al., 1971). Our findings further confirmed those studies reported by others. One of the interesting findings was the antibody to DNA which has not been reported previously in myasthenia gravis. The antibody to SS-DNA itself is not diagnostic, since it could also be found in other autoimmune disorders (Koffler et al., 1969; Sharp et al., 1971). The source of DNA antigen is not clear at present. However, a high incidence, $40 \%$ in our study, of DNA antibody should raise a possibility that DNA may have been derived from an exogenous agent, such as a virus. One of the three cases who also had antibody to DS-DNA was suspected of having clinical systemic lupus erythematosus. Since this antibody is diagnostic only for that disease, all three cases warrant close observation.

Probably the most important antibody found in the sera of myasthenic patients in this study is an antithymus antibody. The presence of this antibody has been reported previously (Strauss et al., 1960; Beutner et al., 1962; Van der Geld and Strauss, 1966) although its incidence varied in different studies. We chose thymic cell suspensions instead of tissue sections as substrate in order to obtain better identification of cells. We felt that the higher incidence that we detected may be attributed to the difference in the technique.

Few known ATAs found in the autoimmune diseases will react to lymphocytes at $37^{\circ} \mathrm{C}$. Most are reported to have cold lymphocytotoxicity, which reacts especially at $15^{\circ} \mathrm{C}$ (Mittal et al., 1970; Terasaki et al., 1970; Wernet and Kunkel 1973). Other ATAs, although not cytotoxic, showed an immunosuppressive activity at $37^{\circ} \mathrm{C}$ (Wernet and Kunkel, 1973). Since many myasthenic patients still showed normal lymphocyte counts, it is unlikely that their ATA were lymphocytotoxic at normal body temperature. Indeed, in our preliminary study on seven serum samples, four showed a significant lymphocytotoxicity at $15^{\circ} \mathrm{C}$. It was also interesting to find that all four patients showed poor responses to mitogen stimulations in vitro.

Recently a high incidence of antibody to acetylcholine receptors or a binding factor to its adjacent site have been found in the sera of myasthenia gravis patients (Appel et al., 1975; Bender et al., 1975; Mittag et al., 1976). This antibody is thought to act as a blocking factor on the neuromuscular transmission in these patients. Although acetylcholine receptors are most commonly found in skeletal muscles, it has been suggested also that there is a special cell population (myoid cells) in the thymus which possess acetylcholine receptors (Strauss et al., 1966; Aharonov et al., 1975). A recent study showed that cultures of dissociated human thymus yielded cells identical to skeletal muscle with respect to morphology, contractility, electrophysiological properties, and the presence of acetylcholine receptors (Kao and Drachman, 1977; Wekerte and Ketelsen, 1977). Our preliminary observation indicated that ATA was able to bind myoid cells in thymus as judged by their morphology as fluorescent positive cells. A further study, such as an alpha-bungarotoxin binding assay, should allow us to define further the nature of ATA in myasthenic patients.

Thus, the high incidence of thymic abnormality and the existence of antithymus antibodies in myasthenia gravis patients should not be considered solely coincidental. It is tempting to speculate that ATA may be the first autoantibody which causes the alteration of the histology and functions of the thymus. Altered thymic function appears to involve primarily its helper cell and suppressor cell activity. IgA deficiency in myasthenic patients could be due to the loss of helper cell activity. On the other hand, the loss of suppressor cell activity may have resulted in the high frequency of autoimmune phenomena and elevation of serum IgE in some patients. It appears also that one of the autoantibodies, antiAch receptor antibody, is the most important factor for the development of the clinical neuromuscular weakness. In some cases it may be postulated that a further change of $\mathrm{T}$ cell has led to a decrease in $\mathrm{T}$ cell number or poor response to mitogen stimulations. Indeed, a steady change of $T$ cells or its subset after a prolonged exposure to ATA has been reported in an animal model of systemic lupus erythematosus (Shirai et al., 1972; Stobo et al., 1972; Stutman, 1972). Recent reports on abnormal response of mixed lymphocytethymocyte culture of myasthenia patients (Abdou et al., 1975; Richman et al., 1976) suggest further alterations of $\mathrm{T}$ cell functions.

Studies on the nature of autoimmunity in myasthenia gravis so far support the hypothesis proposed by Simpson (Simpson, 1960; Simpson et al., 1976) that myasthenia gravis is an immunological disease. A further study on the nature and the 
development of antithymus antibody, and a possible connection of this antibody with exogenous agent(s) or genetic susceptibility, should improve our understanding of the pathogenesis of myasthenia gravis.

\section{References}

Abdou, N. I., Lisak, R. P., Zweiman, B., Abrahamsohn, I., and Penn, A. S. (1975). The thymus in myasthenia gravis. New England Journal of Medicine, 291, 1271-1275.

Adner, M. M., Ise, C., Schwab, R. S., and Dameshek, W. (1966). Immunological studies of thymectomized and non-thymectomized patients with myasthenia gravis. Annals of the New York Academy of Sciences, 135, 536-548.

Aharonov, A., Tarrab-Hazdai, R., Abramsky, O., and Fuchs, S. (1975). Immunological relationship between acetylcholine receptor and thymus. A possible significance in myasthenia gravis. Proceedings of the National Academy of Science, USA, 72, 1456-1459.

Ammann, A. J., and Pelger, R. J. (1972). Determination of antibody to pneumococcal polysaccharide with $\mathrm{CrCl}_{3}$-treated human red blood cells and indirect hemagglutination. Applied Microbiology, 24, 679-683.

Appel, S. H., Almon, R. R., and Levy, N. (1975). Acetylcholine receptor antibodies in myasthenia gravis. New England Journal of Medicine, 293, 760761.

Armstrong, R. M., Novak, R. M., Falk, J. A., and Falk, R. E. (1972). In vitro assessment of thymus cells and thymoma cells in myasthenia gravis. In Proceedings of 6th Leukocyte Conference, pp. 657663. Academic Press: New York.

Armstrong, R. M., Novak, R. M., and Falk, R. E. (1973). Thymic lymphocyte function in myasthenia gravis. Neurology (Minneapolis), 23, 1078-1083.

Bender, A. N., Ringle, S. P., Engel, W. K., Daniels, M. P., and Vogel, Z. (1975). Myasthenia gravis: a serum factor blocking acetylcholine receptor of the human neuromuscular junction. Lancet, 1, 607-609.

Beutner, E. H. E., Witebsky, E., Ricken, D., and Adler, R. H. (1962). Studies on autoantibodies in myasthenia gravis. Journal of the American Medical Association, 182, 46-58.

Boyüm, A. (1967). A one-stage procedure for isolation of granulocytes and lymphocytes from human blood. Scandinavian Journal of Clinical and Laboratory Investigation, 21, 51-76.

Field, E. J., Bates, D., Shaw, D. A., Griffin, S. G., Shenton, B. A., and Smith, K. (1973). Lymphocyte sensitization in myasthenia gravis: Function of the adult thymus gland. Lancet, 2, 675-676.

Goust, J. M., Castaigne, A., and Moulias, R. (1974). Delayed hypersensitivity to muscle and thymus in myasthenia gravis and polymyositis. Clinical and Experimental Immunology, 18, 39-47.

Hobbs, J. R. (1968). Immune imbalance in dysgammaglobulinaemia. Lancet, 1, 110-114.
Jondal, M., Holm, G., and Wigzell, H. (1972). Surface markers on human $\mathrm{T}$ and $\mathrm{B}$ lymphocytes. Journal of Experimental Medicine, 316, 207-215.

Junge, U., Koekstra, J., Wolfe, L., and Deinhardt, F. (1970). Microtechnique for quantitative evaluation of in vitro lymphocyte transformation. Clinical and Experimental Immunology, 7, 431-437.

Kao, I., and Drachman, D. B. (1977). Thymic muscle cells bear acetylcholine receptors. Possible relation to myasthenia gravis. Science, 195, 74-75.

Koffler, D., Carr, R. I., Agnello, V., Fiezi, T., and Kunkel, H. G. (1969). Antibodies to polynucleotides: distribution in human serum. Science, 156, 16481649.

Koziner, B., Bloch, J. J., and Perlo, V. P. (1976). B and $\mathrm{T}$ lymphocyte distribution in myasthenia gravis. Annals of the New York Academy of Sciences, 274, 411-420.

Lisak, R. P., Abdou, N. I., Zweiman, B., Zmijewski, C. M., and Penn, A. S. (1976). Aspects of lymphocyte function in myasthenia gravis. Annals of the New York Academy of Sciences, 274, 402-410.

Mittag, T., Kornfeld, P., Tormay, A., and Woo, C. (1976). Detection of antiacetylcholine receptor factors in serum and thymus from patients with myasthenia gravis. New England Journal of Medicine, 294, 691-694.

Mittal, K. K., Rossen, R. D., Sharp, J. T., Lidsky, M., and Butler, W. T. (1970). Lymphocyte cytotoxic antibody in systemic lupus erythematosus. Nature, 225, 1255-1256.

Miyawaki, S., and Ritchie, R. F. (1974). Heterogeneity of antinucleolar antibody in patients with systemic rheumatic diseases. Journal of Immuno$\log y, 113,1346-1352$.

Mori, R., and Kawanami, S. (1973). Destruction of cultural thymus cells by autologous lymphocytes from a patient with myasthenia gravis. Lancet, 1, 210.

Nastuk, W. L., Plescia, O. J., and Osserman, K. E. (1960). Changes in serum complement activity in patients with myasthenia gravis. Proceedings of the Society of Experimental Biology and Medicine, 105, 177-184.

Osserman, K. E. (1969). Myasthenia gravis. In Textbook of Immunopathology, pp. 607-623. Edited by P. A. Miescher and H. J. Müller-Eberhard. Grune and Stratton: New York.

Penn, A. S., Schotland, D. L., and Rowland, L. P. (1971). Immunology of muscle disease. Research Publications. Associations for Research in Nervous and Mental Diseases, 49, 253-257.

Richman, D. P., Patrick, J., and Arnason, B. G. W. (1976). Cellular immunity in myasthenia gravis. Response to purified acetylcholine receptor and autologous thymocytes. New England Journal of Medicine, 294, 694-698.

Ross, G. D., Rabellino, E. M., Polley, M. J., and Grey, H. M. (1973). Combined studies of complement receptors and surface immunoglobulin-bearing cells and sheep erythrocytes rosette forming cells in 
normal and leukemic human lymphocytes. Journal of Clinical Investigation, 53, 377-385.

Sharp, G. C., Irvin, W. S., LaRogue, R. L., Velez, C., Daly, V., Kaiser, A. D., and Halman, H. R. (1971). Association of autoantibodies to different nuclear antigens with clinical patterns of rheumatic disease and responsiveness to therapy. Journal of Clinical Investigation, 50, 350-359.

Shirai, T., Yoshiki, T., and Mellors, R. C. (1972). Thymus dependence of cells in peripheral lymphoid tissues and in the circulation sensitive to natural thymocytotoxic autoantibody in NZB mice. Journal of Immunology, 109, 32-37.

Simpson, J. A. (1960). Myasthenia gravis: a new hypothesis. Scottish Medical Journal, 5, 419-436.

Simpson, J. A. (1966). Myasthenia gravis as an autoimmune disease: clinical aspects. Annals of the New York Academy of Sciences, 135, 506-516.

Simpson, J. A., Behan, P. O., and Dick, H. M. (1976). Studies on the nature of autoimmunity in myasthenia gravis: Evidence for an immunodeficiency type. Annals of the New York Academy of Sciences, 274, 382-389.

Smithers, D. W. (1959). Tumours of the thyroid gland in relation to some general concepts of neoplasia. Journal of the Faculty of Radiologists, 10, 3-16.

Stobo, J. D., Talal, N., and Paul, W. E. (1972). Lymphocyte classes in New Zealand mice. Journal of Immunology, 109, 692-710.

Strauss, A. J. L., Seegal, B. C., Hsu, K. C., Burkholder, P. M., Nastuk, W. L., and Osserman, K. E. 1960). Immunofluorescence demonstration of a muscle binding, complement fixing serum globulin fraction in myasthenia gravis. Proceedings of the Society for Experimental Biology and Medicine, 105, 177-184.

Strauss, A. J. L., Kemp, P. G., Jr., and Douglas, S. D.
(1966). Myasthenia gravis. Immunological relationship between striated muscle and thymus. Thymic myoid cells. Lancet, 1, 772-775.

Stutman, O. (1972). Lymphocyte subpopulations in NZB mice: deficit of thymus-dependent lymphocytes. Journal of Immunology, 109, 602-611.

Terasaki, P. I., Mottironi, V. D., and Barnett, E. V. (1970). Cytotoxins in disease. New England Journal of Medicine, 283, 724-728.

Van der Geld, H. W. R., and Strauss, A. J. L. (1966). Myasthenia gravis: immunological relationship between striated muscles and thymus. Lancet, 1, 5760.

Vyas, G. N., Perkins, H. A., and Fudenberg, H. H. (1968). Anaphylactoid transfusion reactions associated with anti-IgA. Lancet, 2, 312-315.

Waldman, T. A., Bull, J. M., Bruce, R. M., Broder, S., Jost, M. C., Suellen, T., Suer, B., and Suer, M. E. (1974). Serum immunoglobulin in E levels in patients with neoplastic disease. Journal of Immunology, 113, 379-386.

Wekerte, H., and Ketelsen, U-P. (1977). Intrathymic pathogenesis and dual genetic control of myasthenia gravis. Lancet, 1, 678-680. 1977.

Wernet, P., and Kunkel, H. G. (1973). Antibodies to specific surface antigen of $T$ cells in human sera inhibiting mixed leukocyte culture reactions. Journal of Experimental Medicine, 138, 1021-1026.

Williams, R. C., DeBoard, J. R., Mellbye, O. J., Messner, R. P., and Lindstrom, F. D. (1973). Studies of $\mathrm{T}$ - and B-lymphocytes in patients with connective tissue diseases. Journal of Clinical Investigation, 52, 263-295.

Yunis, E. J., Stutman, O., and Good, R. A. (1971). Thymus, immunity and autoimmunity. Annals of the New York Academy of Sciences, 183, 205-220. 